\title{
Social trust and angel investors' decisions: a multilevel analysis across nations
}

\section{Article}

\section{Accepted Version}

Creative Commons: Attribution-Noncommercial-No Derivative Works 4.0

Ding, Z., Au, K. and Chiang, F. (2015) Social trust and angel investors' decisions: a multilevel analysis across nations. Journal of Business Venturing, 30 (2). pp. 307-321. ISSN 0883-9026 doi: https://doi.org/10.1016/j.jbusvent.2014.08.003 Available at https://centaur.reading.ac.uk/70989/

It is advisable to refer to the publisher's version if you intend to cite from the work. See Guidance on citing.

Published version at: https://doi.org/10.1016/j.jbusvent.2014.08.003

To link to this article DOI: http://dx.doi.org/10.1016/j.jbusvent.2014.08.003

Publisher: Elsevier

All outputs in CentAUR are protected by Intellectual Property Rights law, including copyright law. Copyright and IPR is retained by the creators or other copyright holders. Terms and conditions for use of this material are defined in the End User Agreement.

\section{www.reading.ac.uk/centaur}

\section{CentAUR}

Central Archive at the University of Reading

Reading's research outputs online 
Running Head: Institutional Influence on Informal Investors

Institutions and informal investors' decision: A multilevel analysis across countries

Zhujun Ding

Chinese University of Hong Kong

Kevin $\mathrm{Au}$

Chinese University of Hong Kong

Flora Chiang

Baptist University of Hong Kong

Keywords: Entrepreneurship; Institutional Theory; Informal Investment 


\title{
Institutions and informal investors' decision: A multilevel analysis across countries
}

\begin{abstract}
Informal investors' decisions are embedded in and influence by the institutional environment. This paper advanced a multilevel model on how institutional factors moderate the decision of informal investors. It is postulated that formal institutional factors (rule of law, regulation quality) and informal ones (social trust, institutional uncertainty tolerance) can enhance information flow, collaboration, and sanctioning mechanisms in a society; as a result, they moderate the importance of decision factors of informal investors. Multilevel modeling on data from 27 countries (over 90,000 people) shows that the institutional factors heighten the positive relationship between individual's having start-up skills and informal investment, but surprisingly dampen that between seeing opportunity in new business and informal investment. These moderating effects are robust even after wealth, cultural values, and other factors are controlled. This study contributes to the research interaction of entrepreneurship and institutional theory. It also sheds light on the differential effects of improved institutions on informal investment. Different from most people would believe, improved institutions could actually cast adverse effects on informal investment, as smart, opportunity-driven individuals can have many other choices to put their investment.
\end{abstract}




\section{Introduction}

The importance of institutional environment on entrepreneurship has received increasing attention in entrepreneurship research (Bowen and De Clercq, 2008; Bruton et al., 2009; Li and Zahra, 2012). As Baker, Gedajlovic, and Lubatkin (2005: 500) claimed, "entrepreneurial behavior is motivated by a diverse set of motives and is strongly influenced by the social context in which that behavior is embedded". The impact of institutions on key entrepreneurial activities has been investigated in various studies related to firms' innovation, venture capital investment, and highimpact startups across nations (Busenitz et al., 2000; Cumming et al., 2010; Lounsbury and Crumley, 2007). Institutions and institutional processes also shape entrepreneurs' decisions to manage external relations - which suppliers to use, what partnerships to form, and from whom to obtain funding (Tobert et al., 2011). Among these relationships, investor relations are undoubtedly the most significant to entrepreneurs.

In this study, we focus on informal investors (usually well-to-do individuals or retired entrepreneurs) for the significant role they play in financing early-stage new ventures (Knight, 1994; Shane, 2009). Informal investors provide early-stage funding and play an essential role in entrepreneurship activities (Knight, 1994; Shane, 2009). Availability of funding can determine the formation of new ventures (Cassar, 2004; Shane, 2009), and inability to secure funding hurts growth and survival (Aldrich, 1979; Baron and Shane, 2004). Furthermore, capital structure has a pathdependent or imprinting effect on the design and development of new ventures (Cooper et al., 1994), and the kind of early-stage fundings used has a profound effect on the new ventures. Evidence showed that $53 \%$ of all investment in young companies in the US is from informal investors (Reynolds, 2007), exceeding other sources, such as venture capitalists, small business investment companies, banks, and other financial institutions. Without informal investors, many new venture would never exist or wither at the very early stage before venture capitalists or other institutional investors can get involved (Riding, 2008; Szerb et al., 2007). That is why OECD and EU have stepped up their effort to support informal investment due to its pivotal role in promoting entrepreneurship (Wilson, 2011). Despite its importance, informal investment is under-researched when the dominated research attention has been 
on the founding, designing, and networking of new venture and venture capital.

Prior research on informal investors mainly focus on individual qualities, such as demographics, resources, and values (Harrison et al., 1997; Mason and Rogers, 1996). However, as individuals and organizations are embedded in the institutional environment (Baker et al., 2005; Scott, 2001, 2002), their investment decisions are also largely embedded in and influenced by institutions (e.g., Bruton et al., 2009; Meyer et al., 2008; Meyer and Rowen, 1977). Given the research gap, this study aims to examine empirically how institutions influence informal investors' decisions across nations. To this end we propose a model stipulating that both formal institutions (i.e., explicit and codified rules and regulations) and informal institutions (i.e., tacit and unwritten norms and values) affect individuals in making their investment decisions. As suggested in social capital and social trust theories (Hagen and Choe, 1998; Putnum, 1993), the key institutional factors affect information transmitting, cooperation facilitating, and sanction enforcement in the society and thus impact how informal investors make their decision. We tested the multilevel moderation effect of institutions (level 2) on the individual factors, having start-up skills and seeing start-up opportunities (level 1), across countries. The findings confirm most of our hypotheses, and further analyses show that they are robust against several alternative explanations.

This paper contributes to entrepreneurship and institutional studies in three important ways. First, the decision-making process in informal investment research most often focuses on the individual characteristics of informal investors and the antecedents and consequences of investment decisions (Landström, 1995). We contend that institutions moderate the decisions on informal investment, and fill the knowledge gap on whether and how informal investors are influenced by institutions across countries. Second, the investigation of institutional influence on informal investment opens up a new avenue of research on comparative entrepreneurship. By explaining the mechanisms (see further below), this study highlights the influential role of both formal and informal institutions in shaping informal investment decisions. Finally, using multilevel modeling, we capture the cross-level influence of institutions on individual decision making in a multiple country settings (Hitt et al., 2007). Such multilevel cross-country design can improve on previous studies (e.g., Kwon and Arenius, 2010; Traceys et al., 2011; Wong and Ho, 2007) in ascertaining their validity and revealing 
more complicated cross-level institutional influences (Hitt et al., 2007).

\section{Theory and hypotheses}

\subsection{Informal investors and investment decisions}

Limited personal financial capabilities and access to venture capital make more and more entrepreneurs turn to informal investors for funding to finance new ventures (Duxbury et al., 1996; Mason and Harrison, 2002; Prowse, 1998). Informal investors include those who have a close relationship with the entrepreneur (family and friends), and those who have no personal relationship with the entrepreneur (so-called angels) (Shane, 2009). Using data from 28 developed countries, Burke et al. (2010) found that entrepreneurial activities boost the supply of informal investment; however, their study did not look into other important institutional factors, nor moderating effects.

Prior studies conducted in Western countries largely focus on individual factors relating to engagement in informal investment (Wetzel, 1981, 1983). These include psychological states, such as motivations of informal investors (Duxbury et al., 1996), and demographics and personal factors, such as previous investment experience and acquaintance with the entrepreneur (Bygrave and Reynolds, 2004; Landström, 1993, 1995; Mason and Harrison, 1994, 1997, 2000; Maula et al., 2005). Recent studies pay more attention to informal investor's decision making (Maxwell et al., 2011; Mitteness et al., 2012) and strategy use (Wiltbank et al., 2009). Studies that involved non-Western countries have revealed a few consistent individual predictors, such as financial wealth, demographic and entrepreneurial background, and entrepreneurial control (Landström, 1993; Wong and Ho, 2007). Nonetheless, institutional effects, especially those across levels, remain a research gap in the studies of informal investment.

\subsection{Formal and informal institutions}

Institutions may be referred as formal and informal (North, 1990), both are related to investment activities, such as venture capital activities (Guler, 2007; Li and Zahra, 2012). We found that formal institutional factors- rule of law and regulatory quality (Kaufmann, Kraay, \& Mastruzzi, 2010), and 
informal institutional factors - social trust and institutional uncertainty tolerance (North, 1991; Oliver, 1991), are most relevant to the investment decision of informal investors. These four institutional factors were examined for their function to reduce uncertainty and relevance to business transaction. Originated from different schools of thought (DiMaggio and Powell, 1991; Meyer and Rowan, 1977; North, 1991; Scott, 2008), they can cross-validate the results of each other and thus serve as a good starting point for studying informal investment, and can explain cross-national difference in individual and firm behavior in addition to that of culture (Crossland and Hambrick, 2011; Parboteeah and Cullen, 2003; Tosi and Greckhamer, 2004).

Formal institutions refer to the explicit and codified rules and regulations that govern property rights and transactions, reduce uncertainty, and solve problem (North, 1991; Scott, 2001). Rule of Law refers to "the extent to which agents have confidence in and abide by the rules of society, and in particular the quality of contract enforcement, property rights, the police, and the courts, as well as the likelihood of crime and violence" (Kaufmann et al., 2010). Under the effective and impartial law system, informal investors can be more certain about the information they obtained, the other exchange party they work with, and the sanction mechanism if necessary. Regulatory quality captures "the perceptions of the ability of the government to formulate and implement sound policies and regulations that permit and promote private sector development" (Kaufmann et al., 2010). Regulatory quality is about the capacity of the government to effectively implement sound policies (Cubbin and Stern, 2006; La Porta et al., 1998). Since informal investment entails social and financial interactions among founders and investors, regulatory quality affects how informal investors go about doing their investments (Ho and Wong, 2005).

Informal institutions, on the other hand, refer to the tacit and usually unwritten conventions, norms and values that shape social interaction (North, 1990). Social trust is an important societal norm that regulates and governs economic and social behavior, and enables social actors to establish mutual expectations of future behavior (Doney et al., 1998; Fukuyama, 1995; Luhmann, 1979). Social trust, in the sociological stance, is a socially embedded property of relationships among people or institutions (Granovetter, 1985; Zucker, 1986). Trust is critical when dealing with risk and interdependence (Rousseau et al., 1998; Stewart, 2004), which are the kind of conditions that informal 
investors operate (Haar et al., 1988). Also societies vary in their societal institutions that guarantee members' collective seeking of orderliness, consistency, structure, formalized procedures, and laws to sustain their daily life (De Luque and Javidan, 2004; Hofstede, 1991). Institutional uncertainty tolerance (House et al., 2004) captures individual's perception of a society's practice of using rules, regulations and laws to enhance the predictability of future events and to avoid turmoil and instability (Venaik and Brewer, 2010). Uncertainty tolerance serves as a norm that influences business transactions, as it indicates how strong rules are used to deal with uncertainty in society (House et al., 2004), and are found to reduce investment activities such as VC investment ( $\mathrm{Li}$ and Zahra, 2012). Compared to social trust, it emphasizes norm backed up by the use of rules in society and has less to do with mutual expectations, even if it may result in such a consequence. Given its relation to dealing with uncertainty in society, informal investment is affected by this institutional factor.

\subsection{Institutions as moderators of informal investment decision}

Based on the literature (e.g., Bercovitz and Feldman, 2008; Bruton et al., 2009), we posit that individual factors of informal investors not only exert their influence on investment decision directly, but are also largely affected by the institutions. "Entrepreneurial behavior is motivated by a diverse set of motives and is strongly influenced by the social context in which that behavior is embedded" (Baker et al., 2005: 500). Past studies have revealed important decision factors related to the motives of informal investors (Kwon and Arenius, 2010; Szerb et al., 2007; Wong and Ho, 2007). According to the human capital theory, individual's skills and knowledge are important human capital factors that influence their behavior (Becker, 1964). Therefore, this study focuses on two important human capital factors of informal investors, having start-up skills and seeing start-up opportunities, for testing the influence of institutions. These human capital factors of informal investors are also related to established factors explaining why entrepreneurs start a business (e.g., Stephan and Uhlaner, 2010; Kirzner, 1973), so gaining the insight of institutional influence on them would help build an integrated understanding of the entrepreneurial process (Baron and Shane, 2004).

We propose that institutions would affect how informal investors are influenced by these decision factors in their investment decision, through three aforementioned important mechanisms: information 
transmitting, cooperation facilitating, and sanction enforcement. First, good institutions facilitate the transmission and sharing of vital information in a society (Brehm and Rahn, 1997; Putnam, 1993; Seligman, 1997). Those who give credit to information from a variety of sources have a greater chance of becoming involved in better opportunities and "making a fortune". Second, good institutions can facilitate individuals' goodwill in social exchange relationship, reduce conflicts, and enhance cooperation (Sarasvathy et al., 2002). Thus, the spirit of cooperation is promoted while opportunistic behaviors are discouraged (Hagen and Choe, 1998). Third, good institutions facilitate the operation of societal sanction mechanisms that regulate the behavior of social actors (Hagen and Choe, 1998; Yamagishi, 1986). These three mechanisms are conceptually different but related to one another in their operation.

\subsection{Having start-up skills}

Planed behavior theory suggests that the stronger the control one perceives, the more likely one has the intention to perform the behavior (Ajzen, 1991, 2002). The extent to which individuals believe that they have the skills and knowledge necessary to pursue a specific task is an important motivational element required to achieve desired outcome. The sense of control not only fosters feelings of competence and accomplishment but it also affords investors with a greater degree of autonomy and power in deciding how to make their investment decisions; thereby increasing their ability to cope with any possible uncertainties. Informal investor are often interested in entrepreneurial activity, but do not want to do it themselves or have retired from running new venture (Bygrave and Reynolds, 2004; Maula et al., 2005; Scott, 2010). Informal investors do not merely provide funding to the new venture but also expect to add value to and involve in the new venture creation and development process (Mason and Harrison, 1997; Van Osnabrugge and Robinson, 2001). Thus, investors who have more skills, knowledge, and capabilities in entrepreneurial and venturing activities are more likely to have a higher level of control and may be more confident to invest as well as to contribute to the company (Wong and Ho, 2007).

Hypothesis 1a: Individuals who have start-up skills are more likely to make informal investment. 
Investment decisions involve joint problem solving and cooperation among founders, investors, and other stakeholders (Sarasvathy et al., 2002). Conflicts and disputes can easily occur among investors and founders when they exercise control in working with each other. Institutions may facilitate joint problem solving by reducing uncertainty (Dequech, 2001; North, 1990), as they can act as a lubricant (Luhmann, 1979) to promote positive conflict resolution for the long-term prospect of cooperation even when differences emerge among investors and entrepreneurs. A good rule of law and high quality regulatory framework promotes individual's faith in the government and society, and gives them the long-term prospect to work out differences with founders and together invest perpetually in start-ups. High social trust in society promotes shared moral values and mutually expected honesty by increasing openness, reducing conflicts, and facilitating joint problem solving and cooperation when disputes occur (Dyer and Chu, 2003). When trust exists, people would be more positive with relational exchange, thereby reducing risk and uncertainty in investment. In addition, individuals in a society of high uncertainty tolerance emphasize procedural consistency and formality in interactions with others (House et al., 2004), thereby reducing the chance for misunderstanding and conflicts. Practices that ensure a greater level of information, clarity, and control should be more desirable, making negotiation and conflict resolution more efficient. Thus, with benign institutions, individuals with skills to help new venture would find making collaboration easier and become even more interested to invest in new ventures.

Hypothesis 1b: Institutional factors heighten the positive relationship between individual's having start-up skills and making informal investment.

\subsection{Seeing start-up opportunities}

Informal investors make risky investments expecting for positive return (Van Osnabrugge and Robinson, 2001). They are facing similar decisions like entrepreneurs who start new companies (Hisrich et al., 2007). Entrepreneurial alertness (Kirzner, 1973) is crucial to entrepreneurs, as new business venturing is preceded by a state of heightened alertness and capability to information. Informal investors who see opportunities may be said to possess "investor alertness", which would be 
a state of heightened alertness and capability to spot profitable deals for optimizing the return of their capital and other resources (Maula et al., 2005). Just like entrepreneurs, they need to develop as a habit of scanning their environment for information that may solve unmet needs and to combine resources in a novel fashion (Busenitz and Lau, 1996) in order to capture investment opportunities on new startups. For potential investors then, having the investor alertness in seeing opportunities would make them more ready to invest in new businesses.

Hypothesis 2a: Individuals who see start-up opportunities are more likely to make informal investment.

Institutions, formal and informal, act as a lubricant to facilitate economic and social development (Luhmann, 1979). Specifically, high regulatory quality makes sure the laws are implemented effectively and are understood by people (North, 1990). People thus spend less time and cost on checking and monitoring entrepreneurs who give approvals and encouragement to invest (Cummings et al., 2010; La Porta et al., 1997, 1998). Social trust can reduce enforcement costs simply as individuals internalize the values behind laws and regulations. People in trusting societies engage in mutual monitoring, treat others honestly and give accurate investment and company information (Fukuyama, 1995; Yamagishi, 1986; Yamagishi et al., 1998). Lastly, uncertainty tolerance gives individual the confidence that rules are used to deal with uncertain situations related to investment (de Luque and Javidan, 2004), as order is in place and uncertainty is less likely.

Overall, when good institutions prevails, the economy and society can benefit and many opportunities will arise (Zak and Knack, 2001). However, such lubricant may not benefit new business venturing only, but, as previous studies show, benefits established companies as well (La Porta et al., 1997). This creates the interesting situation regarding how people alert of investment opportunities would appropriate their resources. As Baker et al. (2005: 497) put it, "it is not the value of the opportunity, per se, that is most relevant ... but rather the appropriable benefits - the portion of the value of an opportunity that a potential entrepreneur expects to be able to capture for their own purposes." Accordingly, informal investors, similar to entrepreneurs, should try to capture value in a way that benefits them the most. In other words, individuals who see good opportunities will naturally 
apportion their time and resources into established asset classes (e.g., mutual funds) but not just new ventures.

Informal investing in new businesses may not be attractive enough to people in economies with good institutions simply because the better environment has facilitated the development and supply of investment products that carry lower risk and, discounting the transaction costs, provide a higher and stable return (Berger and Udell, 2003). In comparison, startups are usually less organized, uncertain, and risky. Besides, even if informal investment is attractive, it is unfortunately not commonly perceived as 'proper' practice (Meyer and Rowen, 1977), and that is why OECD governments try to facilitate and promote it (Wilson, 2011). Therefore, in an economy of good environment, people seeing opportunities in new ventures may simply act as what most smart individuals would do - tap into stocks and bonds instead of investing in new business startups. This means that institutional factors may weaken the positive relationship between seeing start-up opportunity and making informal investment.

Hypothesis 2b: Institutional factors weaken the positive relationship between individual's seeing start-up opportunities and making informal investment.

\section{Method}

\subsection{Data}

We used validated data from several reliable sources. The individual-level data was derived from the Global Entrepreneurship Monitor's (GEM) Adult Population Survey (APS), which have contributed to a growing number of papers (e.g., Bowen and De Clercq, 2008; Estrin et al., 2012; Kwon and Arenius, 2010; Stephan and Uhlaner, 2010; Wong et al., 2005). In each country participating in the GEM APS, an academic team conducted a harmonized survey on a representative sample of adults (18-64 years old). To ensure adequate country numbers, we combined GEM 2007 and GEM 2005 adult population survey (Levie and Autio, 2008). After matching the country-level data and deleting missing data, we obtained 93,552 individuals across 27 countries in total. The sample size ranges from 485 individuals in New Zealand to 20,823 individuals in Spain. We 
compared the countries included to those excluded, and found there is no significant difference in the score of informal investor propensity for included countries $(\mathrm{M}=4.30, \mathrm{SD}=5.302)$ and excluded countries $(\mathrm{M}=3.44, \mathrm{SD}=2.21) ; \mathrm{t}(38)=0.733, \mathrm{p}<0.23$. This indicates that there is no material difference between the selected and unselected countries, although the former group, which is composed of the major economic entities, has a slightly higher GDP and entrepreneurship level. Despite its wide coverage, we do need to caution that the GEM sample under-represents African and Middle Eastern countries. Other country-level data come from World Bank, World Values Survey (WVS), GLOBE study, the GEM Expert Survey, and Hofstede's (1991). The use of secondary data has both strengths and weaknesses (Au and Kwan, 2008; McGrath et al., 1982). We thus employed variables with proven validity, and strove to eliminate possible confounding effects by including such control variables as GDP, TEA, and cultural values.

- Table 1 goes about here -

\subsection{Dependent variable}

The dependent variable is the individual informal investment decision. It was measured by asking respondents "whether [you] have, in the past three years, personally provided funds for a new business started by someone else, excluding any purchases of stocks or mutual funds?" $(1=$ yes; $0=$ no). As a recurring measure of informal investment propensity in GEM studies, this measure has been widely used in previous studies to identify informal investors (Bygrave and Reynolds, 2004; Maula et al., 2005; Szerb et al., 2007; Wong and Ho, 2007) and other management research, such as investment strategy (Holburn and Zelner, 2010), entrepreneurship (Davidsson and Honig, 2003), and new venture financing (Hallen, 2008). The average ratio of informal investors to total observations is $4.9 \%$, with the largest ratio of $29.3 \%$ in India and the smallest ratio of $0.63 \%$ in Brazil.

\subsection{Independent variables}

The independent variables depict the focal individual attributes that lead to informal investment. Previous studies using GEM have used single items as proxies for focal variables, instead of full measurement scales. We used only measures validated in past studies (e.g., Levie and Autio, 2008; 
Wong and Ho, 2007). Having start-up skills was proxied by asking the respondents whether they had the knowledge, skill, and experience required to start a new business $(1=$ yes; $0=$ no $)$. Seeing start-up opportunity was measured by asking the respondents whether they felt that there were good opportunities to start a business in the area in which they lived in the next six months $(1=$ yes; $0=$ no). The dichotomous variables and single items may impose certain constraints because the use of secondary data does not permit as much flexibility and precision as the use of primary data but has been the practice, especially in a cross-national study with many countries pooled together and a large sample size in total (e.g., Parboteeah et al., 2008; Wanous et al., 1997).

\subsection{Moderators}

The national level moderators come from different sources. The fact that their results converged (see Results below) confer more confidence on their validity. Rule of law and regulatory quality come from World Bank Governance indices estimated by Kaufmann et al. (2007) . The World Bank research group claims that "Governance consists of the traditions and institutions by which authority in a country is exercised". They are granted as the credible and precise measures of governance, used in various studies (e.g., Cumming et al., 2010; Globerman and Shapiro, 2003). Among the six related indices, we focused on the two that are most closely related to our entrepreneurship and the informal investment context. The rest are related more to democracy and stability of society.

Social trust comes from the World Values Survey (WVS). Trust is difficult to measure directly so researchers could only use indirect measure - indices or signals on the likely presence or absence of trust (Zucker, 1986). In the WVS, social trust is proxied by the percentage of individuals in each country who believe that others can be trusted as measured by the question, "In general, do you think that most people can be trusted, or can't you be too careful in dealing with people?" Measured as a percentage of population, it is not an individual-level variable, but a society-level variable that indicates the general level of societal trust toward others (Kozlowski and Klein, 2000). It represents the attitude toward "most people" rather than that toward particular individuals, and makes no indication of the context, as even the most trusting individual will consider others untrustworthy in certain conditions (Uslaner, 2002). The validity of this measurement has been demonstrated in 
previous papers (e.g., La Porta et al., 1997; Kwon and Arenius, 2010), and similar measures have been used in the U.S. census and other academic studies (e.g., Blanchflower and Freeman, 1997; Knack and Keefer, 1995; Miller and Mitamura, 2003). We combined data from two waves of the WVS to obtain enough country samples (see also Kwon and Arenius, 2010), 24 countries from the fifth wave (2005-2007) and 3 from the fourth (1999-2001). To determine whether this combination makes sense, we selected 21 countries in both waves and found the trust measure to be strongly correlated across these two waves $(r=0.887, p<0.001)$. As shown in Table 2, Turkey exhibits the lowest level of social trust (4.8\%), and Sweden the highest (68.0\%).

For institutional uncertainty tolerance, we use uncertainty avoidance practices index from GLOBE as a proxy (Sully de Luque and Javidan, 2004) . The GLOBE study separated the practice and value measures for each of their cultural dimensions to capture both the tangible attributes of culture, such as the current policies and practices, and the intangible attributes, such as cultural values (Hanges and Dickson, 2004). The cultural practices measured in GLOBE are currently the only validated measures of descriptive norms (House et al., 2004; Stephan and Uhlaner, 2010). UA practices reveal people's perceived orderliness and security in a society, whereas UA values capture people's aspiration and desire toward social structure (Venaik and Brewer, 2011). Given the interest of this study to measure informal institutions, the UA practices index was deemed relevant (de Luque and Javidan, 2004).

\subsection{Control variables}

We employed several control variables at the individual and country levels. At the individual level, gender, age, household income, education, GEM wave and whether the respondents know entrepreneurs were used as control variables, as they have found to be related to informal investment in previous research (e.g., Bygrave and Reynolds, 2004). At the country level, we used the logarithm of GDP (Purchasing Power Parity) from the CIA database and the Total Entrepreneurship Activities index (TEA) from the GEM survey as control variables. GDP can affect an individual's investment decisions, as a country's wealth determines its level of investment activities and general institutional environment. The TEA index measures the proportion of a nation's adult population that is engaged in 
entrepreneurial activities, including starting up a business or running a newly formed business. A country active in entrepreneurship should enjoy strong investment interest among its populace (Burke et al., 2010). In the subsequent tests on robustness, we also studied possible confounding effects cultural values, looking into cultural dimensions that are related to social trust and business transactions (Lim et al., 2004; Li and Zahra, 2012), namely power distance (PDI), individualismcollectivism (IDV), and uncertainty avoidance (UAI) (Hofstede, 1991).

\section{Results}

Hierarchical linear modeling (HLM) was used to test the multilevel hypotheses (Hitt et al., 2007; Klein et al., 1994). In using this approach, this study constitutes an advance on past findings with cross-country and multilevel data, as individual behavior is embedded in the institutional environment. Since our dependent variable is a binary variable, we employed logistic regression with the Bernoulli outcome variable in HLM. Table 3 presents the summary statistics and correlations.

- Table 2 goes about here -

\subsection{Hypotheses testing}

We estimated several HLM models to test the hypotheses. The four institutional factors are theoretically relevant to each other. In the analysis, we put them separately into the models (Crossland and Hambrick, 2011), although combining the four into one factor yielded the same results as well (see details later).

A null model with no predictors specified was first analyzed. Then we added variables in a incremental manner, as shown in Table 4. Model 1 suggests that all two independent variables have a significantly positive relationship with informal investment decisions:having start-up skills $(\gamma=0.248$, $p<0.001)$, and seeing start-up opportunities $(\gamma=0.173, p<0.001)$. Therefore, Hypotheses 1a and 2a are supported. This finding therefore verifies previous findings in a multilevel setting.

- Table 3 goes about here -

Level 2 institutional variables were added into the equation to test the existence of cross-level 
moderation (see Models 2-4). Hypothesis $1 \mathrm{~b}$ argues that the relationship between having start-up skills and informal investment decision are positively moderated by the institutions. The results in models 3 and 4 show a positive moderating effect of rule of law $(\gamma=0.079, p<0.05)$ and regulatory quality $(\gamma=0.099, p<0.05)$, respectively. The results in models 5 and 6 also confirmed the moderation effect of social trust $(\gamma=0.535, p<0.01)$ and institutional uncertainty tolerance $(\gamma=$ $0.121, p<0.01)$. Together, Hypothesis $1 \mathrm{~b}$ received support.

Hypothesis $2 \mathrm{~b}$ posits that the relationship between seeing start-up opportunity and informal investment decision are negatively moderated by the institutional factors. The results in models 3,4 , 5, and 6 show negative moderation effect related to rule of law $(\gamma=-0.060, p<0.001)$, regulatory quality $(\gamma=-0.077, p<0.001)$, social trust $(\gamma=-0.229, p<0.05)$, and institutional uncertainty tolerance $(\gamma=-0.089, p<0.001)$. Accordingly, the negative moderating effects of the institutions on seeing start-up opportunity received strong support.

In addition to the foregoing results, a noteworthy finding is that the institutional factors do not exert a direct (or main) effect on informal investment decisions. Benign institutional environment alone does not seem to benefit informal investment directly. Further discussed below, this is in line with our argument related to hypothesis $2 b$; that is, a favorable institutional environment promotes informal investment, but it is far from the only business activity in which people can engage.

\subsection{Robustness of the moderating effects of the institutional factors}

GDP and TEA. Institutions are known to be correlated with several important country variables. It may be that the effect of institutions is spurious, and is caused only by correlated national variables. To rule out this possibility and establish robustness, GDP (Ln) and TEA were added to the model using their interaction with the focal variables, to see if they explained the moderation effects of the institutional factors. After controlling for these moderations, the moderation effects continue to hold up (Models 7-10 in Table 4). Thus, the moderating effects are unlikely the result of wealth and entrepreneurship activities.

Single country effect. We checked whether a single country can affect the results. Among the data, India has a high ratio of informal investors to observations (29.3\%) compared to the average 
$(4.06 \%)$. After excluding India, the results remain to hold. Indeed, we tested that the overall findings are robust no matter if any one or two countries are eliminated in our tests.

Cultural values. We reanalyzed the data by adding culture's effect (both direct and moderation) with three individual characteristics into the model. Here, we employed three of Hofstede's (1991) cultural dimensions that are related to social trust (Lim et al., 2004), namely power distance (PDI), individualism-collectivism (IDV), and uncertainty avoidance (UAI). Country number reduced to 26 due to the availability of the culture data. The institutional effects continue to hold despite the presence of the cultural dimensions. The former is not caused by these cultural effects.

Institutional factors clustered as a theme. The institutional factors have relatively high intercorrelation for the reason that they share the similar underline function. Despite their conceptual differences, it may lend to the idea of clustering them into an institutional theme (Crossland and Hambrick, 2011). Following previous studies (Crossland and Hambrick, 2011; Stephan and Uhlaner, 2010), we used factor analysis to combine the four institutional factors into a second-order factor, and found that this factor exhibited the same moderation effects as the institutional factors.

\section{Discussion}

Institutions should shape not only the behavior of entrepreneurs and venture capitalists, but also that of informal investors in new business venturing. This study focuses on how institutional factors (North, 1990), namely, rule of law, regulatory quality, social trust, and uncertainty tolerance practice, may affect informal investors' decision. Consistent with previous studies in entrepreneurship and venture capital (e.g., Cumming et al., 2010), this study shows evidence that these institutional factors can moderate the decisions of informal investors, based on dozens of country data from GEM and other reliable sources. The findings extend past studies on informal investment and reveal the important role of institutions in shaping investment on new ventures.

Firstly we found that individual decision factors, having start-up skills and seeing start-up opportunity, were positively related to informal investment decisions. The findings confirm previous studies (e.g., Maula et al., 2005) in a multilevel analytic setting, which controls for sample size 
difference across countries and other country-level factors (Kozlowski and Klein, 2000). This extends the external validity of previous findings conducted in a single-level of analysis. More importantly, the HLM analysis on multilevel data reveals that the institutional factors are systematically related to the weights of the individual decision factors of informal investment. The findings support that institutions reduce information uncertainty, facilitate cooperation, and make ease enforcement (e.g., Hagen and Choe, 1998; North, 1990); more importantly, institutions can exert cross-level moderation effects on informal investors' decision that benign environment, as indicated by the formal and informal institutional factors, heightens entrepreneurially efficacious individuals to invest but dampens opportunity-alert individuals to invest in new business ventures.

As the cross-level moderation effects show, while it is readily acceptable that benign institutions would facilitate competent and eager individuals to invest in new ventures, it is less obvious that such favorable context may divert opportunity-alert individuals to move their investment away to other more reliable and profitable asset classes. The explanation may be that on one hand, better institutions make available better investment channels (Bruton et al., 2009; Meyer et al., 2008) and opportunities (Knack and Keefer, 1995; La Porta et al., 1998; Zak and Knack, 2001), and smart individuals certainly know how to appropriate their money for the best opportunities (Baker et al., 2005). Along this line of thought, what also deserved attention is that the institutional factors do not exert a direct effect on informal investment decision. We believe that this null direct effect is in line with the above argument. Although favorable institutions have a positive effect on economic growth and provide a benign environment for informal investment, a predictable, well-governed environment also facilitates other kinds of economic and business activities. These activities and opportunities compete for capital and other resources on investment to the best opportunities (Baker et al., 2005). On the other hand, "normative expectations and socially shared assumptions often drive organizational decision making and practices" (Tolbert et al., 2011: 1333), and people in general are socialized (Meyer and Rowen, 1977) or "structured" (North, 1990) to see informal investment as more risky and less profitable than the conventional asset classes (Wilson, 2011). After all, conventional investment are asset classes that have been developed much longer and have legitimized themselves after years of development (Cumming et al., 2010; Shane, 2009). 


\section{Implication}

Since institutions are found to moderate key individual decision factors, this study extends informal investment as an entrepreneurship behavior that is subject to institutional influence (Baker et al., 2005), similar like the cases of new venture creation (Aldrich and Fiol, 2007; Bowen and De Clercq, 2008) and venture capital investment (Bruton et al., 2009; Li and Zahra, 2012). The findings may shed light on directions for future research. First, it seems that good institutions (North, 1990) are useful to heighten confident and competent individuals to do informal investments. In particular, social trust and social uncertainty tolerance were demonstrated empirically as an important constructs for understanding entrepreneurship across nations (Fukuyama, 1995). The moderating effects of the formal and informal institutions are robust and unlikely to be the chance product of confounding variables, such as wealth and cultural values. The fact that the effects of formal and informal institutions converge may suggest that there is an institutional theme or second-order factor (Crossland and Hambrick, 2011; Stephan and Uhlaner, 2010) related to uncertainty reduction that can affect entrepreneurial behaviors. It is intriguing for future studies to investigate into this possibility.

In addition, while improving law and regulation is a prescription for almost every developing nation as a way to improve its economy, academics and policy makers may need to be careful with all the effects of improving institutions. This may sound paradoxical, but well-regarded policy initiatives, such as deregulations (Djankov et al., 2008), have been shown to be futile, if not detrimental, to nascent entrepreneurship (van Stel et al., 2007). And even though it may be an exception, poor institutions did not stop China's new ventures from rapid development (Allen et al., 2005), and as the recent financial crisis revealed, the financial infrastructures of many developed nations failed to channel capital to the entrepreneurs and small and median enterprises. Hence, to informal investment, the findings of this study suggests that whilst improving institutions prompts individuals with entrepreneurial skills to invest in new ventures, such move may induce those who see opportunities to divert their capital away to other assets. This is because improving institutional environment is often accompanied by the upswing of the financial market. And financial institutions are more skillful to 
use resources to develop investment tools, unfortunately not of them good, and persuade people to purchase them for investment (Davis, 2009). So future studies shall continue to ask the question of how to improve informal investment especially when there is continuous improvement in institutions. If more informal investment is useful, we may want to boost the entrepreneurial skills of potential investors in order to compensate for the deficit caused by better investment alternatives available to the investors. We need to do more to direct those who see opportunities to informal investment. Apart from presenting them with investment chances and establishing incentives to signal benefits (e.g. tax incentives), and supporting and building more angel business networks are suggested (Wilson, 2011). Future studies can investigate how institutions shape the emergence of new practices and new angel organizations (Sine et al., 2005). In any case, if increasing informal investment is important, we need to be aware of differential effects brought about by improving institutions and find ways to counterbalance them.

Although the findings of this study are interesting, several limitations should be noted when interpreting the results and can direct to future research improvement. First, informal investment at the population level is a relatively rare event, though not serious. Yet, according to King and Zeng (2001a, 2001b), the rare events issue makes the results less significant than they really are; thus producing conversative results. We did not deal with this issue further, as the results of our hypothesis testing are strong, and there are no good methods for studies with a multilevel category variable design. Future studies shall continue to take note of the rare event issue and may find a good way of overcoming this limitation. Second, the dichotomous variables used to measure informal investment reveal only the propensity to invest or not invest. Future analysis of more sophisticated measures would help us to better understand informal investment. The same improvement also applies to the independent variables and may help to extend the study to cover other relevant constructs, such as networks of entrepreneurs (e.g., Aldrich and Zimmer, 1986) and family trust (Miller and Mitamura, 2003).

Third, to capture global entrepreneurial activity, the breadth and depth of measurement is limited in the GEM project. Most of the predictors used in our study are dichotomous for the practical reason that it would be prohibitively expensive to collect more fine-grained data across dozens of countries 
(Maula et al., 2005). Possible confounding variables could be tested in more fine-tuned surveys and through case studies. Single-item measure variables are always subject to criticism. However, when the situational constraints limit the use of scales to the research questions, the employment of singleitem measures is acceptable (Wanous et al., 1997). Our use of only those measures that have been proven in past studies (e.g., Kwon and Arenius, 2010) may alleviate the problem to a certain extent. Lastly, the cross-sectional data do not allow causality to be clearly determined. It may be helpful since we do provide good theoretical reasoning for the identified relationships. Yet future studies could use a longitudinal or experimental design and a different institutional context (e.g., Bercovitz and Feldman, 2008) to verify the results.

To conclude, institutions are found to intersect with entrepreneurship in informal investment in addition to venture capital ( $\mathrm{Li}$ and Zahra, 2012). This study focuses on national institutional factors and its interaction with individual qualities and decision factors. It is hoped that future studies continues to explore other institutions related to organization, class, industry and certainly other microfoundations of entrepreneurship (Zahra and Wright, 2011). 


\section{Reference}

Ajzen, I., 1991. The theory of planned behavior. Organizational Behavior Human Decision Process $50,179-211$.

Ajzen, I., 2002. Perceived behavioral control, self-efficacy, locus of control and the theory of planned behaviour. Journal of Applied Social Psychology 32, 1-20.

Aldrich, H. E., 1979. Organizations and environments. PrenticeHall, Englewood Cliffs, NJ.

Aldrich, H. E., Fiol, C. M., 1994. Fools rush in? The institutional context of industry creation. Academy of Management Review 19, 645-670.

Aldrich, H. E., Zimmer, C., 1986. Entrepreneurship through social networks. In Sexton, D., Smilor, R. (Eds.), The art and science of entrepreneurship, 3-23. Ballinger, Cambridge, MA.

Allen, F., Qian, J., Qian, M., 2005. Law, finance, and economic growth in China. Journal of Financial Economics 77, 57-116.

Au, K., Kwan, H. K., 2009. Start-Up Capital and Chinese Entrepreneurs: The Role of Family. Entrepreneurship Theory Practice 33, 889-908.

Baker, T., Gedajlovic, E., Lubatkin, M., 2005. A framework for comparing entrepreneurship processes across nations. Journal of International Business Studies 36(5), 492-504.

Baron, R. A., Shane, S., 2004. Entrepreneurship: A process perspective. Southwestern Thomson, Cincinnati, $\mathrm{OH}$.

Bandura, A., 1982. Self-efficacy mechanism in human agency. American Psychologist 37, 122-147.

Becker, G. S., 1964. Human capital (3rd ed.). University of Chicago Press, Chicago.

Bercovitz, J., Feldman, M., 2008. Academic entrepreneurs: organizational change at the individual level. Organization Science 19(1), 69-89.

Berger, A. N., Udell, G. F., 2003. Small business and debt finance. In Acs, Z. J., and Audretsch, D. B. (Eds.), Handbook of entrepreneurship research: An interdisciplinary survey and introduction, 299-328. Kluwer Academic Publishers, Boston.

Blanchflower, D. G., Freeman, R. B., 1997. The attitudinal legacy of communist labor relations. Industrial and Labor Relations Review 50(3), 438-459.

Bowen, H. P., De Clercq, D., 2008. Institutional context and the allocation of entrepreneurial effort. Journal of International Business Studies 39(4), 747-767.

Brehm, J., Rahn., W. M., 1997. Individual-level evidence for the causes and consequences of social capital. American Journal of Political Science 41(3), 999-1023.

Bruton, G., D., Ahlstrom, D. C., Puky, T., 2009. Institutional differences and the development of entrepreneurial ventures: A comparison of the venture capital industries in Latin America and Asia. Journal of International Business Studies 40(5), 762-778.

Bruton, G. D., Khavul, S., Chavez, H., 2011. Microlending in emerging economies: Building a new line of inquiry from the ground up. Journal of International Business Studies 42(5), 18-739.

Burke, A. E., Hartog, C. M., van Stel, A. J., Suddle, K., 2010. How does entrepreneurial activity affect the supply of informal investors? Venture Capital 12(1), 21-47.

Busenitz, L. W., Gömez, C., Spencer, J. W., 2000. Country institutional profiles: Unlocking entrepreneurial phenomena. Academy of Management Journal 43(5), 994-1003.

Busenitz, L., Lau. C. M., 1996. A cross-cultural cognitive model of new venture creation. Entrepreneurship Theory Practice 20(4), 25-39.

Bygrave, W. D., Reynolds, P. D., 2004. Who finances startups in the USA? A comprehensive study of informal investors, 1998-2003. Frontiers of entrepreneurship research. Babson Park, MA, Babson College.

Cassar, G., 2004. The financing of business start-ups. Journal of Business Venturing 19, 261-283.

Cooper, A. C., Gimeno-Gascon, F. J., Woo, C. Y., 1994. Initial human and financial capital as predictors of new venture performance. Journal of International Business Studies 9(5), 371395.

Crossland, C., Hambrick, D. C., 2011. Differences in managerial discretion across countries: how nation-level institutions affect the degree to which CEOs matter. Strategic Management Journal 32(8), 797-819. 
Cubbin, J., Stern, J., 2006. The impact of regulatory governance and privatization on electricity industry generation capacity in developing economies. World Bank Economic Review 20(1), $115-141$.

Cumming, D., Schmidt, D., Walz, U., 2010. Legality and venture capital governance around the world. Journal of Business Venturing 25, 54-72.

Davidsson, P., Honig, B., 2003. The role of social and human capital among nascent entrepreneurs. Journal of Business Venturing 18, 301-331.

Davis, G. F., 2009. The rise and fall of finance and the end of the society of organizations. Academy of Management Perspectives 23(3), 27-44.

De Luque, M. S., Javidan, M., 2004. Uncertainty avoidance. In House, R. J., Hanges, P. J., Javidan, M., Dorfman, P. W., Gupta, V. (Eds.), Culture, leadership and organizations: The GLOBE study of 62 societies, 602-653. Sage, Thousand Oaks, CA.

Dequech, D. 2001. Bounded Rationality, Institutions, and Uncertainty. Journal of Economic Issues 35(4), 911-930.

DiMaggio, P. J., Powell, W. W., 1991. Introduction. Powell, W. W., DiMaggio, P. J. (Eds.), The New Institutionalism in Organizational Analysis, 1-28. University of Chicago Press, Chicago.

Djankov, S., La Porta, R., Lopez-de-Silanes, F., Shleifer, A., 2008. The law and economics of selfdealing. Journal of Financial Economics 88, 430-465.

Doney, P. M., Cannon, J. P., Mullen, M. R., 1998. Understanding the influence of national culture on the development of trust. Academy of Management Review 23(3), 601-620.

Duxbury, L. G., Haines, G., Riding, A., 1996. A personality profile of Canadian informal investors. Journal of Small Business Management 34(2), 44-55.

Dyer, J. H., Chu, W. J., 2003. The role of trustworthiness in reducing transaction costs and improving performance: empirical evidence from the United States, Japan, and Korea. Organization Science 14(1), 57-68.

Estrin, S., Korosteleva, J., Mickiewicz, T., 2012. Which institutions encourage entrepreneurial growth aspirations. Journal of Business Venturing, in press.

Fukuyama, F., 1995. Trust: the social virtues and the creation of prosperity. Free Press, New York.

Globerman, S., Shapiro, D., 2003. Governance infrastructure and US foreign direct investment. Journal of International Business Studies 34(1), 19-39.

Granovetter, M., 1985. Economic action and social structure: The problem of embeddedness. American Journal of Sociology 91(1), 481-510.

Guler, I., 2007. Throwing good money after bad? Political and institutional influences on sequential decision making in the venture capital industry. Administrative Science Quarterly 52(2), 248285.

Haar, N. E., Starr, J., MacMillan, C., 1988. Informal risk capital investors: Investment patterns on the East Coast of the U.S.A. Journal of Business Venturing 3(1), 11-29.

Hagen, J. M., Choe, S., 1998. Trust in Japanese interfirm relations: Institutional sanctions matter. Academy of Management Review 23(3), 589-600.

Hallen, B. L., 2008. The causes and consequences of initial network positions of new organizations: From whom do entrepreneurs receive investments? Administrative Science Quarterly 53, 685718.

Hanges, P. J., Dickson, M. W., 2004. The development and validation of the GLOBE Culture and Leadership Scales. In House, R. J., Hanges, P. J., Javidan, M., Dorfman, P. W., Gupta, V. (Eds.), Leadership, culture, and organizations: The GLOBE study of 62 societies, 122-151. Sage, Thousand Oaks, CA.

Harrison, R. T., Dibben, M. R., Mason, C. M., 1997. The role of trust in the informal investor's investment decision. Entrepreneurship Theory Practice 21(4), 63-81.

Hisrich, R., Langan-Fox, J., Grant, S., 2007. Entrepreneurship Research and Practice: A Call to Action for Psychology. American Psychologist 62(6), 575-589.

Hitt, M. A., Beamish, P. W., Jackson, S. E., Mathieu, J. E., 2007. Building theoretical and empirical bridges across level: Multilevel research in management. Academy of Management Journal 50(6), 1385-1399.

Ho, Y. P., Wong, P. K., 2005. Impact of sources of financing and regulatory business costs on national entrepreneurial propensity. Paper presented at the 2nd GEM Research Conference, Budapest, 
Hungary, 25-27 May.

Hofstede, G. 1991. Cultures and organizations: Software of the mind. McGraw-Hill, London, UK.

Holburn, G. L. F., Zelner, B. A., 2010. Political capabilities, policy risk, and international investment strategy: Evidence from the global electric power generation industry. Strategic Management Journal 31(12), 1290-1315.

House, R. J., Hanges, P. J., Javidan, M., Dorfman, P. W., Gupta, V., 2004. Culture, leadership and organizations: The GLOBE study of 62 societies. Sage, Thousand Oaks, CA.

Kaufmann, D., Kraay, A., Mastruzzi, M., 2007. Governance Matters VI: Aggregate and Individual Governance Indicators 1996-2006. The World Bank, Washington, DC.

Kaufmann, D., Kraay, A., Mastruzzi, M., 2010. The worldwide governance indicators: methodology and analytical Issues. World Bank Policy Research Working Paper No. 5430.

King, G., Zeng, L., 2001a. Explaining rare events in international relations. International Organization 55(3), 693-715.

King, G., Zeng, L., 2001b. Logistic regression in rare events data. Political Analysis 9(2), 137-163.

Kirzner, I., 1973. Competition and Entrepreneurship. University of Chicago Press, Chicago.

Klein, K. J., Dansereau, F., Hall, R. J., 1994. Levels issues in theory development, data collection, and analysis. Academy of Management Review 19, 195-229.

Knack, S., Keefer, P., 1995. Institutions and Economic Performance: Cross-Country Tests Using Alternative Measures. Economics and Politics 7, 207-227.

Knight, R. M., 1994. Criteria used by venture capitalists: a cross cultural analysis. International Small Business Journal 13(1), 26-37.

Kozlowski, S. W. J., Klein, K. J., 2000. A multilevel approach to theory and research in organizations: Contextual, temporal, and emergent processes. In Klein, K. J., Kozlowski, S. W. J. (Eds.), Multilevel theory, research, and methods in organizations: Foundations, extensions, and new directions: 3-90. Jossey-Bass, San Francisco, CA.

Kwon, S. W., Arenius, P., 2010. Nations of entrepreneurs: A social capital perspective. Journal of Business Venturing 25(3), 315-330.

La Porta, R., Lopez-de-Silanes,F., Shleifer, A., Vishny, R. W., 1997. Trust in large organizations. American Economic Review 87(2), 333-338.

La Porta, R., Lopez-de-Silanes,F., Shleifer, A., Vishny, R. W., 1998. Law and finance. Journal of Political Economy 106(6), 1113-1155.

Landström, H., 1993. Informal risk capital in Sweden and some international comparisons. Journal of Business Venturing 8(6), 525-540.

Landström, H., 1995. A pilot study on the investment decision-making behavior of informal investors in Sweden. Journal of Small Bus Management 33(3), 67-76.

Levie, J., Autio, E., 2008. A theoretical grounding and test of the GEM model. Small Business Economics 31(3), 235-263.

Li, Y., Zahra, S., 2012. Formal institutions, culture, and venture capital activity: A cross-country analysis. Journal of Business Venturing 27 (1), 95-111.

Lim, K. H., Leung, K., Sia, C. L., Lee, M. K. O., 2004. Is eCommerce boundary-less? Effects of individualism-collectivism and uncertainty avoidance on Internet shopping.Journal of International Business Studies 35(6), 45-559.

Lounsbury, M., Crumley, E. T., 2007. New practice creation: An institutional perspective on innovation. Organization Studies 28(7), 993-1012.

Luhmann, N., 1979. Trust and power. Wiley, Chichester.

Mason, C. M., Harrison, R. T., 1994. The informal venture capital market in the UK. In Hughes, A., Storey, D. J. (Eds.), Financing small firms, 64-111. Routledge, London.

Mason, C. M., Harrison, R. T., 1997. Business angel networks and the development of the informal venture capital market in the U.K.: Is there still a role for the public sector? Small Business Economics 9(2), 111-123.

Mason, C. M., Harrison, R. T., 2002. Is it worth it? The rates of return from informal venture capital investments. Journal of Business Venturing 17(3), 211-236.

Mason, C. M., Rogers, A., 1996. Understanding the business angel's investment decision. Venture Finance Working Paper No. 14, University of Southampton and University of Ulster, Southampton. 
Maula, M., Autio, E., Arenius, P., 2005. What drives micro-angel investments? A large sample study of factors explaining micro-angel investments. Small Business Economics 25(5), 459-475.

Maxwell, A. L., Jeffrey, S. A., Lévesque, M., 2011. Business angel early stage decision making. Journal of Business Venturing 26(2), 212-225.

McGrath, J., Martin, J., Kukla, R., 1982. Judgment calls in research. Sag, Beverly Hills, CA.

Meyer, K. E., Estrin, S.,Bhaumik, S. K., Peng, M. W., 2008. Institutions, resources, and entry strategies in emerging economies. Strategic Management Journal 31(1), 61-80.

Meyer, J. W., Rowan, B., 1977. Institutionalized organizations: Formal structure as myth and ceremony. American Journal of Sociology 83(2), 340-363.

Miller, A. S., Mitamura, T., 2003. Are surveys on trust trustworthy? Social Psychology Quarterly 66(1), 62-70.

Mitteness, C., Sudek, R., Cardon, M. S., 2012. Angel investor characteristics that determine whether perceived passion leads to higher evaluations of funding potential. Journal of Business Venturing 27(5), 592-606.

North, D. C., 1990. Institutions, Institutional Change and Economic Performance. Cambridge University Press, Cambridge, U.K.

North, D. C., 1991. Institutions. The Journal of Economic Perspectives 5(1), 97-112.

Parboteeah, K. P., Cullen, J. B., 2003. Social institutions and work centrality: explorations beyond national culture. Organization Science 14 (2), 137-148.

Parboteeah, K. P., Hoegl, M., Cullen, J. B., 2008. Managers' gender role attitudes: A country institutional profile approach. Journal of International Business Studies 39, 795-813.

Prowse, S., 1998. Angel investors and the market for angel investments. Journal of Banking and Finance 22(6-8), 785-192.

Putnam, R. D., 1993. The prosperous community: Social capital and public life. American Prospect $13,35-42$.

Reynolds, P., 2007. Entrepreneurship in the US: The future is now. Springer, New York.

Riding, A. L., 2008. Business angels and love money investors: segments of the informal market for risk capital. Venture Capital 10(4), 355-369.

Rousseau, D. M., Sitkin, S. B., Burt, R. S., Camerer, C., 1998. Not so different after all: A crossdiscipline view of trust. Academy of Management Review, 12(3) 393-404.

Sarasvathy, S. D., Dew, N., Velamuri, S. R., Venkataraman, S. 2002. Three views of entrepreneurial opportunity. In Audretsch, D., Acs, Z. (Eds.), International handbook of entrepreneurship: 141-160. Kluwer, Boston, MA.

Scott, W. R., 2001. Institutions and organizations. Sage Publications, Thousand Oaks, CA.

Scott, W. R., 2002. The changing world of Chinese enterprise: An institutional perspective. In Tsui, A. S., Lau, C. M. (Eds.), The management of enterprises in the People's Republic of China: 5978. Kluwer Academic Publishers, London.

Scott, W. R., 2008. Institutions and Organizations: Ideas and Interests. Sage, Thousand Oaks, CA.

Seligman, A., 1997. The problem of trust. Princeton University Press, Princeton, N.J.

Shane, S., 2009. Fool's gold: The truth behind angel investing in America. Oxford University Press, New York.

Sine, W. D., Haveman, H. A., Tolbert, P. S., 2005. Risky Business: Entrepreneurship in the New Independent-Power Sector. Administrative Science Quarterly 50(2), 200-232.

Stephan, U., Uhlaner, L. M., 2010. Performance-based vs socially supportive culture: A cross-national study of descriptive norms and entrepreneurship. Journal of International Business Studies 41, $1347-1364 .$.

Stewart, K. J., 2004. Trust transfer on the world wide web. Organization Science 14(1), 5-17.

Sully de Luque, M., Javidan, M., 2004. Uncertainty avoidance. In House, R. J., Hanges, P. J., Javidan, M., Dorfman, P. W., Gupta, V. (Eds.), Leadership, culture, and organizations: The GLOBE study of 62 societies, 122-151. Sage, Thousand Oaks, CA.

Szerb, L., Rappai, G., Makra, Z., Terjesen, S., 2007. Informal investment in transition economies: Individual characteristics and clusters. Small Business Economics 28(2-3), 257-271.

Tolbert, P. S., David, R. J., Sine, W. D., 2011. Studying Choice and Change: The Intersection of Institutional Theory and Entrepreneurship Research. Organization Science 22(5), 1332-1344.

Tosi, H. L., Greckhamer, T. 2004. Culture and CEO compensation. Organization Science 15 (6), 657 - 
670.

Tracey, P., Phillips, N., Jarvis, O., 2011. Bridging Institutional Entrepreneurship and the Creation of New Organizational Forms: A Multilevel Model. Organization Science 22(1), 60-80.

Uslaner, E. M., 2002. The moral foundations of trust. Cambridge University Press, Cambridge, UK.

Van Osnabrugge, M., Robinson, R. J., 2001. The influence of a venture capitalist's source of funds. Venture Capital 3(1), 25-39.

Van Stel, A., Storey, D., Thurik, A. R., 2007. The effect of business regulations on nascent to young business entrepreneurship. Small Business Economics 28(2-3), 171-186.

Venaik, S., Brewer, P., 2010. Avoiding uncertainty in Hofstede and GLOBE. Journal of International Business Studies 41(8), 1294-1315.

Wanous, J. P., Reichers, A. E., Hudy, M. J. 1997. Overall job satisfaction: How good are single-item measures? Journal of Applied Psychology 82, 247-252

Wetzel, W. E. J., 1981. Informal risk capital in New England. In Vesper, K. H. (Ed.), Frontiers of entrepreneurship research: 217-245. Wellesley, MA: Babson College.

Wetzel, W. E. J., 1983. Angels and informal risk capital. Sloan Management Review, Summer 23-34.

Wilson, K., 2011. Financing high growth firms: the role of angel investors. OECD Publishing. (http://dx.doi.org/10.1787/9789264118782-en).

Wiltbank, R., Read, S., Dew, N., Sarasvathy, S. D., 2009. Prediction and control under uncertainty: Outcomes in angel investing Journal of Business Venturing 24 (2), 116-133.

Wong, P. K., Ho, Y. P., 2007. Characteristics and determinants of informal investment in Singapore. Venture Capital 9(143), 43-70.

Wong, P. K., Ho, Y. P., Autio, E., 2005. Entrepreneurship, innovation and economic growth: Evidence from GEM data. Small Business Economics 24, 335-350.

Yamagishi, T., 1986. The provisioning of a sanctioning system as a public good. Journal of Personality and Social Psychology 51(1), 110-116.

Yamagishi, T., Cook, K. S., Watabe, M., 1998. Uncertainty, trust, and commitment formation in the United States and Japan. American Journal of Sociology 104(1), 165-194.

Yeung, A. C. L., Lo, C. K. Y., Cheng, T. C. E., 2011. Behind the iron cage: an institutional perspective on ISO 9000 adoption and CEO compensation. Organization Science 22(6), 1600-1612.

Zacharakis, A. L., McMullen, J. S., Shepherd, D. A., 2007. Venture capitalists' decision policies across three countries: An institutional theory perspective. Journal of International Business Studies 38, 691-708.

Zahra, S.A., Wright, M. 2011. Entrepreneurship's next act. Academy of Management Perspectives 25, 67-83.

Zak, P. J., Knack, S., 2001. Trust and growth. Economic Journal 111(470), 295-321.

Zucker, L. G., 1986. Production of trust: Institutional sources of economic structure, 1840-1920. In Staw, B. M., Cummings, L. (Eds.), Research in organizational behavior 8, 53-111. JAI Press, Greenwich, CT.

Zucker, L. G., Darby, M. R., Brewer, M. B., 1998. Intellectual human capital and the birth of U.S. biotechnology enterprises. American Economic Review 88(1), 290-306. 
Table 1 List of the 27 countries $^{\text {a }}$

\begin{tabular}{|c|c|c|c|c|c|c|c|c|}
\hline & $\begin{array}{l}\text { GEM country } \\
\text { category (income) }^{\mathbf{b}}\end{array}$ & $\begin{array}{l}\text { Investor } \\
\%\end{array}$ & $\begin{array}{l}\text { Legality } \\
\text { Quality }\end{array}$ & Social Trust & UAIP & $\begin{array}{l}\text { TEA } \\
\%\end{array}$ & $\begin{array}{l}\text { GDP PPP } \\
\text { international } \\
\$ \text { Billion }\end{array}$ & $\begin{array}{l}\text { Total Number } \\
\text { of respondents }\end{array}$ \\
\hline Argentina & Middle\&Low 2 & 3.68 & -1.34 & 0.17 & 3.65 & 11.95 & 471.25 & 1607 \\
\hline Austria & High & 3.04 & 1.08 & 0.48 & 4.39 & 10.9 & 696.83 & 1057 \\
\hline Brazil & Middle\&Low 2 & 0.63 & -1.05 & 0.09 & 3.6 & 12.0 & 1712.79 & 2558 \\
\hline China & Middle\&Low 1 & 7.64 & -1.01 & 0.52 & 4.94 & 15.05 & 6208.89 & 2523 \\
\hline Colombia & Middle\&Low 2 & 6.33 & -0.92 & 0.14 & 3.57 & 22.7 & 344.09 & 1489 \\
\hline Finland & High & 3.31 & 1.13 & 0.59 & 5.02 & 5.95 & 173.83 & 1544 \\
\hline France & High & 4.72 & 0.67 & 0.19 & 4.43 & 4.3 & 352.01 & 2688 \\
\hline Germany & High & 2.28 & 0.98 & 0.34 & 5.19 & 5.4 & 2587.68 & 2746 \\
\hline Hong Kong & High & 6.90 & 1.14 & 0.41 & 4.32 & 10.0 & 268.20 & 1032 \\
\hline India & Middle\&Low 1 & 29.3 & -0.88 & 0.23 & 4.15 & 8.5 & 2772.52 & 616 \\
\hline Israel & High & 1.85 & 0.34 & 0.23 & 4.01 & 5.4 & 177.27 & 851 \\
\hline Italy & High & 2.34 & -0.28 & 0.29 & 3.79 & 4.95 & 1744.76 & 1181 \\
\hline Japan & High & 1.22 & 0.57 & 0.39 & 4.07 & 3.25 & 4085.18 & 1456 \\
\hline Mexico & Middle\&Low 2 & 3.83 & -0.82 & 0.16 & 4.18 & 5.9 & 1394.17 & 1607 \\
\hline Netherlands & High & 1.84 & 1.10 & 0.44 & 4.7 & 4.8 & 609.78 & 2723 \\
\hline New Zealand & High & 4.24 & 1.07 & 0.51 & 4.75 & 17.6 & 102.84 & 485 \\
\hline Russia & Middle\&Low 1 & 1.46 & -1.49 & 0.27 & 2.88 & 2.7 & 1896.62 & 1161 \\
\hline Slovenia & High & 2.44 & 0.09 & 0.18 & 3.78 & 4.6 & 50.19 & 2377 \\
\hline South Africa & Middle\&Low 1 & 1.67 & -0.41 & 0.17 & 4.34 & 5.1 & 433.29 & 1603 \\
\hline Spain & High & 2.96 & 0.34 & 0.20 & 3.97 & 6.65 & 1298.69 & 20823 \\
\hline Sweden & High & 2.23 & 1.15 & 0.68 & 5.32 & 4.1 & 314.12 & 2692 \\
\hline Switzerland & High & 4.18 & 1.17 & 0.51 & 5.175 & 6.2 & 289.38 & 3522 \\
\hline Thailand & Middle\&Low 1 & 5.15 & -0.70 & 0.42 & 3.93 & 23.8 & 482.91 & 3308 \\
\hline Turkey & Middle\&Low 1 & 4.50 & -0.63 & 0.05 & 3.63 & 5.6 & 859.99 & 1067 \\
\hline United Kingdom & High & 1.20 & 1.06 & 0.30 & 4.65 & 5.85 & 2051.41 & 17784 \\
\hline United States & High & 4.51 & 0.86 & 0.39 & 4.15 & 11.0 & 13052.85 & 1960 \\
\hline Venezuela & Middle\&Low 2 & 2.66 & -2.30 & 0.16 & 3.44 & 22.6 & 299.09 & 1508 \\
\hline
\end{tabular}

a Countries are in alphabetical order.

b GEM divide countries into: high-income countries; middle- and low-income 1 countries (Europe and Asia); middle and low-income 2 countries (Latin America and Caribbean). 
Table 2 Descriptive Statistics and Correlations ${ }^{a}$

\begin{tabular}{|c|c|c|c|c|c|c|c|c|c|c|c|c|c|c|c|c|}
\hline Variable & Means & s.d. & 1 & 2 & 3 & 4 & 5 & 6 & 7 & 8 & 9 & 10 & 11 & 12 & 13 & 14 \\
\hline \multicolumn{17}{|l|}{ Level 1 variables } \\
\hline 1.Having start-up skills & 0.40 & 0.49 & & & & & & & & & & & & & & \\
\hline 2.Seeing start-up opportunities & 0.40 & 0.49 & 0.220 & & & & & & & & & & & & & \\
\hline 3.Gender & 0.51 & 0.50 & -0.080 & -0.118 & & & & & & & & & & & & \\
\hline 4.Age & 4121 & 13.9 & -0.073 & -0.151 & 0.008 & & & & & & & & & & & \\
\hline 5.Income & 0.93 & 0.79 & 0.084 & 0.120 & -0.089 & -0.049 & & & & & & & & & & \\
\hline 6.Education & 1.40 & 0.49 & 0.040 & 0.084 & -0.028 & -0.060 & 0.235 & & & & & & & & & \\
\hline 7.GEM Wave & 0.61 & .0 .49 & 0.039 & 0.011 & 0.010 & -0.029 & 0.004 & 0.083 & & & & & & & & \\
\hline 8.Knowing Entrepreneur & 0.53 & 0.50 & 0.230 & 0.258 & -0.151 & -0.035 & 0.122 & 0.078 & 0.010 & & & & & & & \\
\hline 9.Investment & 0.05 & 0.21 & 0.073 & 0.152 & -0.057 & -0.019 & 0.058 & 0.042 & 0.010 & 0.098 & & & & & & \\
\hline \multicolumn{17}{|l|}{ Level 2 variables } \\
\hline 10.TEA & 9.14 & 6.19 & & & & & & & & & & & & & & \\
\hline 11.GDP (Ln) & 2.87 & 0.56 & & & & & & & & & & -0.116 & & & & \\
\hline 12.Rule of Law & 0.69 & 1.03 & & & & & & & & & & 0.006 & 0.046 & & & \\
\hline 13.Regulatory Quality & 0.82 & 0.56 & & & & & & & & & & -0.418 & 0.040 & 0.952 & & \\
\hline 14.Trust & 0.31 & 0.17 & & & & & & & & & & -0.024 & 0.132 & 0.628 & 0.572 & \\
\hline 15.Uncertainty Tolerance & 4.22 & 0.60 & & & & & & & & & & -0.211 & 0.029 & 0.733 & 0.656 & 0.729 \\
\hline
\end{tabular}

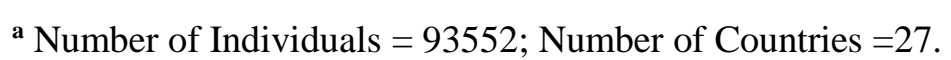


Table 3 Hierarchical Linear Modeling Results for Informal Investment Decisions a

\begin{tabular}{|c|c|c|c|c|c|c|c|c|c|c|}
\hline & Model 1 & Model 2 & Model 3 & Model 4 & Model 5 & Model 6 & Model 7 & Model 8 & Model 9 & Model 10 \\
\hline \multicolumn{11}{|l|}{$\bar{L}$ Level-1 Effect } \\
\hline Intercept & $-2.679(0.125)^{* * *}$ & $-2.682(0.121)^{* * *}$ & $-2.674(0.123)^{* * *}$ & $-2.677(0.121)^{* * *}$ & $-2.677(0.121)^{* * *}$ & $-2.677(0.121)^{* * *}$ & $-2.640(0.117)^{* * *}$ & $-2.641(0.114)^{* * *}$ & $-2.647(0.117)^{* * *}$ & $-2.648(0.117)^{* * * *}$ \\
\hline Income & $0.182(0.013)^{* * *}$ & $0.182(0.013)^{* * * *}$ & $0.181(0.012)^{* * * * *}$ & $0.181(0.012)^{* * *}$ & $0.180(0.018)^{* * *}$ & $0.180(0.012) * * *$ & $0.176(0.012)^{* * * *}$ & $0.176(0.012)^{* * * *}$ & $0.177(0.012)^{* * * *}$ & $0.177(0.012)^{* * *}$ \\
\hline Education & $0.092(0.018)^{* * *}$ & $0.092(0.018)^{* * * *}$ & $0.091(0.017)^{* * *}$ & $0092(0.017)^{* * *}$ & $0.092(0.017)^{* * *}$ & $0.091(0.018)^{* * * *}$ & $0.089(0.017)^{* * *}$ & $0.089(0.017)^{* * *}$ & $0.091(0.017)^{* * *}$ & $0.089(0.017)^{* * *}$ \\
\hline Gender & $-0.159(0.014)^{* * *}$ & $-0.159(0.014)^{* * *}$ & $-0.159(0.013)^{* * *}$ & $-0.159(0.015)^{* * *}$ & $-0.159(0.013)^{* * *}$ & $-0.158(0.013)^{* * *}$ & $-0.155(0.013)^{* * *}$ & $-0.156(0.013)^{* * *}$ & $-0.156(0.013)^{* * *}$ & $-0.155(0.013)^{* * *}$ \\
\hline Age & $0.004(0.001)^{* * *}$ & $0.004(0.001)^{* * * *}$ & $0.004(0.001)^{* * *}$ & $0.004(0.001)^{* * *}$ & $0.004(0.001)^{* * *}$ & $0.004(0.001)^{* * * *}$ & $0.004(0.001)^{* * *}$ & $0.004(0.001)^{* * *}$ & $0.004(0.001)^{* * * *}$ & $0.004(0.001)^{* * *}$ \\
\hline GEM wave & $-0.072(0.087)^{*}$ & $-0.071(0.036)^{*}$ & $-0.069(0.036)+$ & $-0.070(0.036)^{*}$ & $-0.067(0.037)+$ & $-0.068(0.036)+$ & $-0.068(0.034)^{*}$ & $-0.069(0.034)^{*}$ & $-0.065(0.035)+$ & $0.067(0.035)+$ \\
\hline Knowing Entrepreneur & $0.574(0.044)^{* * *}$ & $0.571(0.043)^{* * * *}$ & $0.555(0.045)^{* * * *}$ & $0.561(0.042)^{* * *}$ & $0.558(0.043)^{* * *}$ & $0.564(0.045)^{* * * *}$ & $0.522(0.042)^{* * *}$ & $0.529(0.038)^{* * * *}$ & $0.525(0.042)^{* * * *}$ & $0.529(0.043)^{* * *}$ \\
\hline Having start-up skills & $0.248(0.033)^{* * *}$ & $0.245(0.031)^{* * * *}$ & $0.254(0.029) * * *$ & $0.267(0.027)^{* * *}$ & $0.241(0.028)^{* * *}$ & $0.229(0.028)^{* * * *}$ & $0.234(0.030) * * *$ & $0.242(0.027)^{* * * *}$ & $0.234(0.028)^{* * * *}$ & $0.224(0.030)^{* * *}$ \\
\hline Seeing start-up opportunities & $0.173(0.015)^{* * *}$ & $0.169(0.015)^{* * * *}$ & $0.165(0.015)^{* * * *}$ & $0.159(0.014)^{* * *}$ & $0.174(0.013)^{* * *}$ & $0.180(0.013)^{* * *}$ & $0.164(0.015)^{* * *}$ & $0.153(0.014)^{* * * *}$ & $0.173(0.013)^{* * *}$ & $0.184(0.013)^{* * *}$ \\
\hline \multicolumn{11}{|l|}{ Level-2 Effect } \\
\hline TEA & & $0.029(0.016)+$ & $0.040(0.014)^{*}$ & $0.040(0.016)^{*}$ & $0.029(0.016)+$ & $0.031(0.015)^{*}$ & $0.019(0.008)^{*}$ & $0.011(0.014)$ & $0.017(0.007)^{*}$ & $0.020(0.007)^{* *}$ \\
\hline GDP (Ln) & & $0.132(0.179)$ & $0.149(0.1795)$ & $0.120(0.162)$ & $0.120(0.162)$ & $0.142(0.163)$ & $0.273(0.201)$ & $0.243(0.169)$ & $0.265(0.212)$ & $0.265(0.213)$ \\
\hline Rule of Law & & & $0.069(0.094)$ & & & & $0.022(0.080)$ & & & \\
\hline Regulatory Quality & & & & $-0.023(0.211)$ & & & & $-0.102(0.200)$ & & \\
\hline Trust & & & & & $-0.085(0.447)$ & & & & $-0.081(0.400)$ & \\
\hline Uncertainty Tolerance & & & & & & $0.137(0.075)+$ & & & & $0.114(0.078)$ \\
\hline \multicolumn{11}{|l|}{ Cross-level Moderation } \\
\hline $\begin{array}{l}\text { Rule of Law } \times \\
\text { Having start-up skills }\end{array}$ & & & $0.063(0.027)^{*}$ & & & & $0.048(0.026)+$ & & & \\
\hline $\begin{array}{l}\text { Rule of Law } x \\
\text { Seeing start-up opportunities }\end{array}$ & & & $-0.060(0.016)^{* * *}$ & & & & $-0.079(.023)^{* *}$ & & & \\
\hline $\begin{array}{l}\text { Regulatory Quality } \times \\
\text { Having start-up skills }\end{array}$ & & & & $0.099(0.037)^{*}$ & & & & $0.086(0.037) *$ & & \\
\hline $\begin{array}{l}\text { Regulatory Quality } x \\
\text { Seeing start-up opportunities }\end{array}$ & & & & $-0.077(0.017)^{* * *}$ & & & & $-0.097(0.025)^{* * *}$ & & \\
\hline $\begin{array}{l}\text { Trust } \times \\
\text { Having start-up skills }\end{array}$ & & & & & $0.535(0.177)^{* *}$ & & & & $0.535(0.177)^{* *}$ & \\
\hline
\end{tabular}




\begin{tabular}{|c|c|c|c|c|c|c|c|c|c|c|}
\hline $\begin{array}{l}\text { Trust } \times \\
\text { Seeing start-up opportunities }\end{array}$ & & & & & $-0.229(0.0$ & & & & $-0.224(0.089)^{*}$ & \\
\hline $\begin{array}{l}\text { Uncertainty Tolerancex } \\
\text { Having start-up skills }\end{array}$ & & & & & & $0.121(0.039$ & & & & $0.095(0.049)+$ \\
\hline $\begin{array}{l}\text { Uncertainty Tolerancex } \\
\text { Seeing start-up opportunities }\end{array}$ & & & & & & $-0.089(0.024)$ & & & & $-0.091(0.026)^{* *}$ \\
\hline $\begin{array}{l}\text { TEA } \times \\
\text { Having start-up skills }\end{array}$ & & & & & & & $-0.005(0.004)$ & $-0.003(0.004)$ & $-0.008(0.003)^{*}$ & $-0.005(0.004)$ \\
\hline $\begin{array}{l}\text { TEA } \times \\
\text { Seeing start-up opportunities }\end{array}$ & & & & & & & $-0.005(0.004)$ & $-0.004(0.003)$ & $-0.002(0.001)^{*}$ & $-0.001(0.002)$ \\
\hline $\begin{array}{l}\text { LnGDP } \times \\
\text { Having start-up skills }\end{array}$ & & & & & & & $0.071(0.056)$ & $0.081(0.054)$ & $0.052(0.048)$ & $0.045(0.052)$ \\
\hline $\begin{array}{l}\text { LnGDP } \times \\
\text { Seeing start-up opportunities }\end{array}$ & & & & & & & $-0.007(0.037)$ & $-0.003(0.036)$ & $0.017(0.035)$ & $0.024(0.031)$ \\
\hline $\begin{array}{l}\text { Pseudo R2 } \\
\text { (Incremental) }\end{array}$ & $18.4 \%$ & $30.48 \&$ & $38.53 \%$ & $36.09 \%$ & $30.06 \%$ & $34.99 \%$ & $39.59 \%$ & $33.66 \%$ & $37.42 \%$ & $35.24 \%$ \\
\hline
\end{tabular}

${ }^{a}$ Number of Individuals $=93552 ;$ Number of Countries $=27$.

$+\mathrm{p}<0.10 ; * \mathrm{p}<0.05 ; * * \mathrm{p}<0.01 ; * * * \mathrm{p}<0.001$. 